\section{Journal of Anatolian Environmental and Animal Sciences (Anadolu Çevre ve Hayvancılık Bilimleri Dergisi) \\ Doi: https://doi.org/10.35229/jaes.635310}

\title{
Determination of the Optimum Feed Rate and Spindle Speed Depending on the Surface Roughness of Some Wood Species Processed with CNC Machine
}

\author{
Evren Osman ÇAKIROĞLU*1 Aydın DEMIR ${ }^{2} \quad$ İsmail AYDIN $^{2}$ \\ ${ }^{1}$ Artvin Çoruh University, Artvin Vocational School, Materials and Material Processing Technologies City Campus, 08000, Artvin, Turkey. \\ ${ }^{2}$ Karadeniz Technical University, Department of Forest Industry Engineering Kanuni Campus, 61080 Trabzon, Turkey. \\ (DD: https://orcid.org/0000-0001-5303-8967, (D): https://orcid.org/0000-0003-4060-2578, (D): https://orcid.org/0000-0003-0152-7501
}

Abstract: In modern furniture industry, CNC machines are widely used, especially when high quality of product and flexibility of manufacturing process are expected. Even though there are many advanced computer-aided manufacturing systems for furniture producers, it is difficult to set process parameters according to obtain desired material surface properties because wood is a natural polymeric material with a heterogeneous structure. Wood surface properties are affected both material and machining factors, such as wood species, anatomical characteristics, moisture content, grain direction, feed rate, spindle speed, cutting depth, and tool geometry. In this study, it was aimed to determine of the optimum feed rate and spindle speed depending on the surface roughness of some wood species processed with CNC machine. Spruce, chestnut, larch and iroko were used as wood species. Three spindle speed (10000, 14000 and $18000 \mathrm{rpm})$ and feed rate (5000, 7000 and $9000 \mathrm{~mm} / \mathrm{min}$ ) were determined for CNC processing. The surface roughness (Rz) of wood samples were determined according to DIN 4768 standard. As a result of the study, the lowest surface roughness values were found in $10000 \mathrm{rpm}$ spindle speed and $5000 \mathrm{~mm} / \mathrm{min}$ feed rate for spruce and chestnut wood and $18000 \mathrm{rpm}$ spindle speed and $7000 \mathrm{~mm} / \mathrm{min}$ feed rate for larch and iroko wood. The highest values in the all of wood species were obtain from $10000 \mathrm{rpm}$ spindle speed and $9000 \mathrm{~mm} / \mathrm{min}$ feed rate.

\section{CNC Tezgâhında İşlenmiş Bazı Ağaç Türlerinin Yüzey Pürüzlülüğüne Bağlı Olarak Optimum Besleme Hızı ve Dönüş Hızının Belirlenmesi}

Öz: Modern mobilya endüstrisinde, özellikle yüksek kaliteli ürünün ve esnek üretim sürecinin beklendiği durumlarda CNC makineleri yaygın olarak kullanılmaktadır. Mobilya üreticileri için birçok gelişmiş bilgisayar destekli üretim sistemi olmasına rağmen, ahşap malzemenin heterojen bir yapıya sahip doğal bir polimerik malzeme olması nedeniyle, istenen malzeme yüzey özelliklerini elde etmek için işlem parametrelerinin ayarlanması zordur. Ahşap yüzey özellikleri, ağaç türleri, anatomik özellikler, rutubet, lif yönü, besleme hızı, dönüş hızı, kesme derinliği ve takım geometrisi gibi malzeme ve işleme faktörlerini etkilenmektedir. Bu çalışmada, CNC tezgahında işlenen bazı ağaç türlerinin yüzey pürüzlülüğüne bağlı olarak optimum besleme hızı ve dönüş hızının belirlenmesi amaçlanmıştır. Ağaç türü olarak ladin, kestane, melez ve iroko kullanılmıştır. CNC işlemi için, üç farklı dönüş hızı (10000, 14000 ve 18000 dev/dk) ve üç farklı besleme hızı (5000, 7000 and $9000 \mathrm{~mm} / \mathrm{dk}$ ) belirlenmiştir. Örneklerin yüzey pürüzlülüğü (Rz), DIN 4768 standardına göre belirlenmiştir. En düşük yüzey pürüzlülüğü değerleri, ladin ve kestane için; $10000 \mathrm{dev} / \mathrm{dk}$ dönüş hızı ve $5000 \mathrm{~mm} / \mathrm{dk}$ besleme hızında bulunurken, mele ve iroko için 18000 dev/dk dönüş hızı ve $7000 \mathrm{~mm} / \mathrm{dk}$ besleme hızında bulunmuştur. Tüm ağaç türü gruplarında en yüksek değerler ise, $10000 \mathrm{dev} / \mathrm{dk} \mathrm{dönüş} \mathrm{hızı} \mathrm{ve} 9000 \mathrm{~mm} / \mathrm{dk}$ besleme hızından elde edilmiştir. 


\section{INTRODUCTION}

Wood and wood based materials have been used as a construction material for years, mostly because of low cost, renewability, strength and low processing energy requirements. In recent years, the machining of wood products has acquired great importance, due to the short supply of wood and increasing environmental awareness among users and manufacturers (Sofuoglu, 2017).

Working with automatic mechanical equipment demands precise, accuracy, speed, consistency and flexibility. In this case it takes the help of embedded computer applications to do the job. One of the mechanical equipment combined with microcomputer that has been widely used is a CNC machine (Computer Numerical Controlled). CNC machines are used for mechanical work such as cutting, engraving, drilling and others. The computer technology used to control, parse and execute certain objects based on user command. In the manufacturing industry, the use of CNC machines greatly affects the increased production (Jayachandraiah et al., 2014; Ginting et al., 2017). CNC machines are used in various manufacturing applications such as steel machining, plastic cutting, etc. and are widely used in the woodworking industry. In the furniture industry, CNC machines perform drilling, milling, sanding and cutting operations (Koc et al., 2017). These machines provide high productivity increasing the efficiency up to 2.5 times and flexibility in production and integration to automation systems (Raja \& Baskar, 2011).

The surface quality of solid wood and wood based panels is one of the most important properties characterizing the wood machining process and its conditions, manufacturing processes, such as finishing or adhesive strength properties. The surface roughness of wood can be affected by different factors, such as annual ring variation, wood density, cell structure, earlywood ratio and latewood ratio, and humidity (Zhong et al., 2013; Sofuoglu, 2017). CNC machining process is a significant stage as it affects surface coating performance such as adhesion strength of coating, minimization of waste and appearance of wood products (Cool \& Hernandez, 2011; Tan et al., 2012; Ozdemir et al., 2015). Surface roughness is a crucial quality indicator of cutting and coating process (Koc et al., 2017). Nas et al. (2012) reported that the surface roughness had changed significantly depending on the parameters as a result of milling the material surfaces in CNC machinery. Wilkowski et al. (2011) utilized Taguchi method to investigate effective factors for CNC processing parameters of wood surface roughness of oak and ash. The cutting parameters such as feed rate and spindle speed were resulted as significant parameters on the surface roughness.

The main purposes of process monitoring and control are to optimize manufacturing speeds and to reduce production times. An effective process monitoring system should alert the operator and shut the machine down when critical conditions are about to be reached. In wood machining, the control process should manage key control variables such as feed rate or spindle speed, and adjust them to approach optimum conditions for the chosen machining objectives (Iskra \& Tanaka, 2005). In this study, it was aimed to determine of the optimum feed rate and spindle speed depending on the surface roughness of some wood species processed with $\mathrm{CNC}$ machine.

\section{MATERIAL and METHODS}

In this study, spruce, chestnut, larch and iroko were used as wood species. Three spindle speed (10000, 14000 and $18000 \mathrm{rpm})$ and feed rate (5000, 7000 and 9000 $\mathrm{mm} / \mathrm{min}$ ) were determined for CNC processing. It is given description of test groups according to wood species in Table 1.

\begin{tabular}{|c|c|c|c|c|c|}
\hline $\begin{array}{l}\text { Wood } \\
\text { Species }\end{array}$ & $\begin{array}{l}\text { Spindle } \\
\text { Speed (rpm) }\end{array}$ & $\begin{array}{l}\begin{array}{l}\text { Feed Rate } \\
(\mathrm{mm} / \mathrm{min})\end{array} \\
\end{array}$ & $\begin{array}{l}\text { Wood } \\
\text { Species }\end{array}$ & $\begin{array}{l}\text { Spindle } \\
\text { Speed (rpm) }\end{array}$ & $\begin{array}{ll}\begin{array}{l}\text { Feed Rate } \\
(\mathbf{m m} / \mathbf{m i n})\end{array} \\
\end{array}$ \\
\hline \multirow{9}{*}{ Spruce } & \multirow{3}{*}{10000} & 5000 & & \multirow{3}{*}{10000} & 5000 \\
\hline & & 7000 & & & 7000 \\
\hline & & 9000 & & & 9000 \\
\hline & \multirow{3}{*}{14000} & 5000 & & \multirow{3}{*}{14000} & 5000 \\
\hline & & 7000 & Chestnut & & 7000 \\
\hline & & 9000 & & & 9000 \\
\hline & \multirow{3}{*}{18000} & 5000 & & \multirow{3}{*}{18000} & 5000 \\
\hline & & 7000 & & & 7000 \\
\hline & & 9000 & & & 9000 \\
\hline \multirow{9}{*}{ Larch } & \multirow{3}{*}{10000} & 5000 & & \multirow{3}{*}{10000} & 5000 \\
\hline & & 7000 & & & 7000 \\
\hline & & 9000 & & & 9000 \\
\hline & \multirow{3}{*}{14000} & 5000 & & \multirow{3}{*}{14000} & 5000 \\
\hline & & 7000 & Iroko & & 7000 \\
\hline & & 9000 & & & 9000 \\
\hline & \multirow{3}{*}{18000} & 5000 & & \multirow{3}{*}{18000} & 5000 \\
\hline & & 7000 & & & 7000 \\
\hline & & 9000 & & & 9000 \\
\hline
\end{tabular}

The wood samples were processed on Megatron 2128, 4 Axis CNC Milling Machine with $9 \mathrm{~kW}$ spindle power, a maximum spindle speed of $24.000 \mathrm{rpm}$. Working area of the machine is $2100 \times 2800 \times 150(\mathrm{~mm}) .2 \mathrm{~mm}$ diameter conical knife were used for all of the groups. The CNC machine and processing of the wood samples are shown in Figure 1.

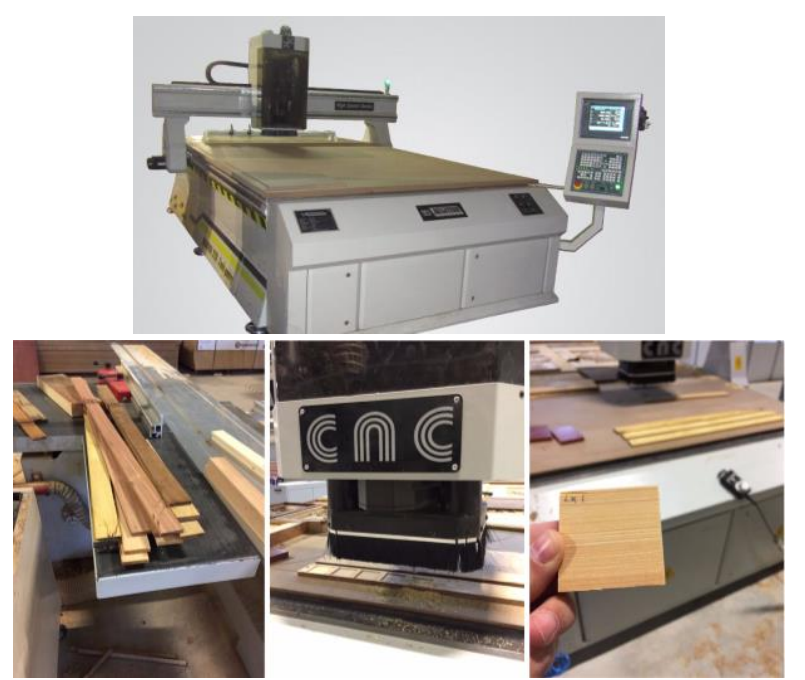

Figure 1. CNC milling machine and Processing of the wood samples. 
A fine stylus-type profilometer, Mitutoyo Surftest SJ-301 Surface Roughness Tester was used for the surface roughness test (Figure 2). This device consists of a main unit and a pickup. The pickup has a skid-type diamond stylus with a radius of $5 \mu \mathrm{m}$ and a tip angle of $90^{\circ}$. Cut off length (kc) was $2,5 \mathrm{~mm}$, and tracing length was $12,5 \mathrm{~mm}$. Ten replicates of wood samples for each group were used for surface roughness measurement. The samples cut at the dimensions of $50 \times 50 \times 10 \mathrm{~mm}$ were used for each test group to evaluate their surface roughness. The $\mathrm{Rz}$ roughness parameter (mean of the 10-point height of irregularities) was used to evaluate surface roughness of the samples according to DIN 4768 (1990).

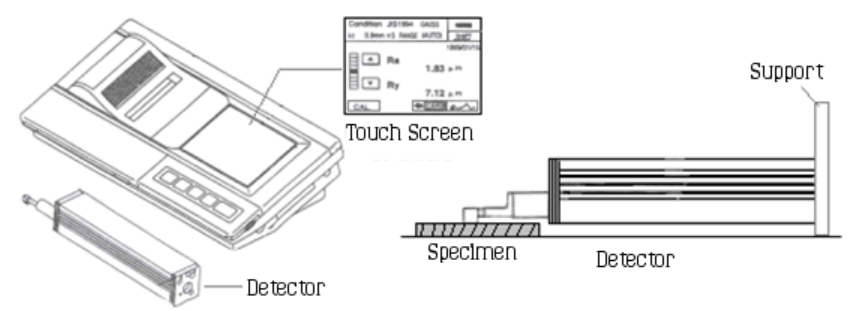

Figure 2. Mitutoyo Surfest SJ-301 surface roughness meter.

\section{RESULTS and DISCUSSION}

The surface roughness mean values $(\mathrm{Rz})$ are given in Figure 3 according to wood species and CNC parameters. The groups that given the lowest roughness values are shown with red arrow.

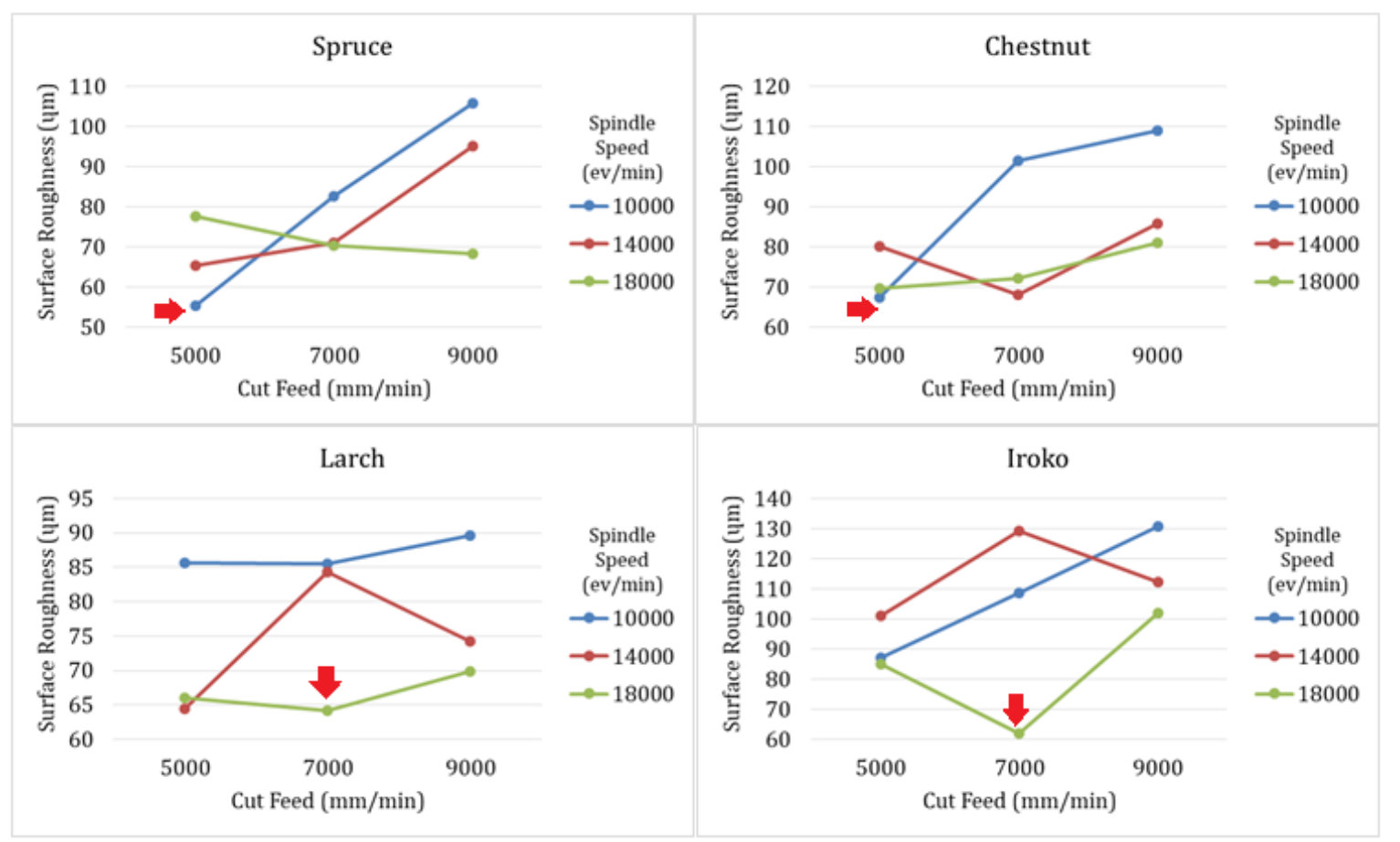

Figure 3. The change of surface roughness mean values according to wood species and CNC parameters.

As can be seen that Figure 2, the lowest surface roughness values were found in $10000 \mathrm{rpm}$ spindle speed and $5000 \mathrm{~mm} / \mathrm{min}$ feed rate for spruce and chestnut wood. Many researchers reported that the effect of feed rate and spindle speed on surface roughness in wood and wood based materials machining, and the results demonstrated that the surface roughness decreases with increasing spindle speed and increases with the feed rate (Iskra \& Tanaka, 2005; Sutcu, 2013; Sutcu \& Karagoz, 2012). In this study, smoothest surfaces for spruce and chestnut were obtained from the lowest spindle speed and feed rate.

However, it was found in $18000 \mathrm{rpm}$ spindle speed and $7000 \mathrm{~mm} / \mathrm{min}$ feed rate for larch and iroko wood. Davim et al. (2009) studied CNC processing parameters of MDF such as spindle speed, cutting speed and feed rate. Higher spindle speed and higher feed rate performed smother surfaces where in the present study lower feed rate and higher spindle speed performed minimum surface roughness. Koc et al. (2017) determined that minimum surface roughness values of MDF, ayous and beech wood were found as spindle speed of 18,000 rpm and feed rate of $2 \mathrm{~m} / \mathrm{min}$ in their study.

The highest values in the all of wood species were obtain from $10000 \mathrm{rpm}$ spindle speed and $9000 \mathrm{~mm} / \mathrm{min}$ feed rate. Sofuoglu (2017) found that the surface roughness, both $\mathrm{Ra}$ and $\mathrm{Rz}$, increased with increasing feed rate, but decreased with increasing spindle speed.

\section{CONCLUSIONS}

CNC wood working machinery has been widely introduced in wood industries, especially in the furniture industry. $\mathrm{CNC}$ has been used for the grooving, milling, patterning of furniture material etc. This technology presents 
many advantages related to output, surface quality and provide greater improvements in productivity, and increase the quality of the machined part. In this study, the effect of various $\mathrm{CNC}$ machine parameters such as spindle speed and feed rate in the wood working processing were investigated on the quality of wood surface. The ranges of $\mathrm{CNC}$ parameters studied in this research are spindle speeds of 10000,14000 and $18000 \mathrm{rpm}$ and feed rates of 5000, 7000 and $9000 \mathrm{~mm} / \mathrm{min}$. As a result of the study, the lowest surface roughness values were found in $10000 \mathrm{rpm}$ spindle speed and $5000 \mathrm{~mm} / \mathrm{min}$ feed rate for spruce and chestnut wood and $18000 \mathrm{rpm}$ spindle speed and $7000 \mathrm{~mm} / \mathrm{min}$ feed rate for larch and iroko wood. The highest values in the all of wood species were obtain from $10000 \mathrm{rpm}$ spindle speed and $9000 \mathrm{~mm} / \mathrm{min}$ feed rate.

\section{REFERENCES}

Cool, J. \& Hernandez, R.E. (2011). Improving the sanding process of Black spruce wood for surface quality and water-based coating adhesion. For. Prod. J., 61, 372-380.

Davim, J.P. Clemente, V.C. \& Silva, S. (2009). Surface roughness aspects in milling MDF (medium density fiberboard). Int. J. Adv. Manuf. Technol., 40, 49-55.

DIN 4768. (1990). Determination of values of surface roughness parameters $\mathrm{Ra}, \mathrm{Rz}, \mathrm{Rmax}$ using electrical contact (stylus) instruments, concepts and measuring conditions. Deutsches Institut für Norming, Berlin, Germany.

Ginting, R., Hadiyoso, S. \& Aulia, S. (2017). Implementation 3-Axis CNC Router for Small Scale Industry. International Journal of Applied Engineering Research, 12(17), 6553-6558.

Iskra, P. \& Tanaka, C. (2005). The influence of wood fiber direction, feed rate, and cutting width on sound intensity during routing. Holz Roh-Werkst, 63, 167172.

Jayachandraiah, B., Krishna, O.V., Khan, P.A. \& Reddy, R.A. (2014). Fabrication of Low Cost 3-Axis CNC Router. Int. J. Eng. Sci. Invent., 3(6), 1-10.

Koc, K.H., Erdinler, E.S., Hazir, E. \& Ozturk, E. (2017). Effect of CNC application parameters on wooden surface quality. Measurement, 107, 12-18.

Nas, E., Samtas, G. \& Demir, H. (2012). Mathematical modelling of parameters effecting surface roughness via CNC routers. J. Eng. Sci., 18, 47-59.
Ozdemir, T., Hiziroglu, S. \& Kocapınar, M. (2015). Adhesion strength of cellulosic varnish coated wood species as function of their surface roughness. Adv. Mater. Sci. Eng., 1-5.

Raja, S.B. \& Baskar, N. (2011). Particle swarm optimization technique for determining optimal machining parameters of different work piece materials in turning operation. Int. J. Adv. Manuf. Technol., 54, 445-463.

Sofuoglu, S.D. (2017). Determination of optimal machining parameters of massive wooden edge glued panels which is made of Scots pine (Pinus sylvestris L.) using Taguchi design method. European Journal of Wood and Wood Products, 75(1), 33-42.

Sutcu, A. (2013). Investigation of parameters affecting surface roughness in $\mathrm{CNC}$ routing operation on wooden EGP. BioResources, 8, 795-805.

Sutcu, A. \& Karagoz, U. (2012). Effect of machining parameters on surface quality after face milling of MDF. Wood Res., 57, 231-240.

Tan, P.L., Sharif, S. \& Sudin, I. (2012). Roughness models for sanded wood surfaces. Wood Sci. Technol., 46, 129-142.

Wilkowski, J., Czarniak, P. \& Grzes'kiewicz, M., (2011). Machinability evaluation of thermally modified wood using the Taguchi technique, in: COST Action FP0904 Workshop Mechano-Chemical Transformations of Wood during Thermo-HydroMechanical (THM) Processing, pp. 109-111.

Zhong, Z.W., Hiziroglu, S. \& Chan, C.T.M. (2013). Measurement of the surface roughness of wood based materials used in furniture manufacture. Measurement, 46, 1482-1487.

\section{*Corresponding author's:}

Evren Osman ÇAKIROĞLU

Artvin Çoruh University, Artvin Vocational School, Materials and Material Processing Technologies City Campus, 08000, Artvin, Turkey.

E-mail : 61evrenosman@artvin.edu.tr

ORCID : https://orcid.org/0000-0001-5303-8967

Phone : +90 (466) 2151075

Fax : : +90(466) 2151076 